\title{
MDC1 wt Allele
}

National Cancer Institute

\section{Source}

National Cancer Institute. MDC1 wt Allele. NCI Thesaurus. Code C104643.

Human MDC1 wild-type allele is located in the vicinity of 6 p21.3 and is approximately 18 $\mathrm{kb}$ in length. This allele, which encodes mediator of DNA damage checkpoint protein 1 , is involved in checkpoint mediated cell cycle arrest. 